\title{
The Macroeconomic Effects of A Disaggregated Government Expenditure Shock in Ethiopia: Evidence from a Bayesian VAR Approach
}

\author{
Kumadebis Tamiru Gemechu \\ Lecturer and J. Research Fellow, Ethiopian Economics Association, Addis Ababa, Ethiopia
}

\begin{abstract}
This paper investigated the macroeconomic effects of government spending shocks in Ethiopia using a Bayesian Vector Auto Regression model. We examined the dynamic responses of output, inflation, interest rate and exchange rate to Government Spending shocks employing quarterly data from 2000/01Q1 to 2015/16Q4. The empirical evidence suggests that government spending shock had a positive impact on output and inflation but the effect was too small. Initially the interest rate responded negatively to government spending shocks and was positive with small effect and the nominal exchange rate showed deterioration. Furthermore, positive shocks to recurrent expenditure had a persistent positive impact on real output. Recurrent expenditure appeared not to be responsible for inflationary pressure. Interest rate picked up slightly as a result of recurrent spending shocks in the short run. The response of exchange rate to recurrent expenditure was small and remained negative. In contrast, capital expenditure was found to have an insignificant effect on output. The reasons could be the administrative lag and contractual bottleneck that are sometimes involved in executing capital projects and that appeared to be responsible for inflationary pressure. In the short term, the interest rate responded negatively and the estimated impact on exchange rate was insignificant.
\end{abstract}

Keywords: Ethiopia, government spending shock, public debt, Bayesian VAR

DOI: $10.7176 / \mathrm{JESD} / 10-19-03$

Publication date:October $31^{\text {st }} 2019$

\section{Introduction}

Fiscal policy is the financial instrument used by the government as a deliberate manipulation of government receipts and expenditures to achieve economic, to allocate resources, stabilize the economy and redistribute income social objectives and maintain stable economic growth (Michaela et al., (2009), Tanzi (2008)). According to Rena et al., (2011) the governance of fiscal policy is a powerful instrument for stabilizing the economy, which controls over the amount and structure of taxes, expenditures, and the debt management. Fiscal policy is one of the instruments with which government in a country employed in the administration of their economy to attain desired objectives (see Medee et al., 2011, Mohamad et al., 2015). It entails those actions initiated by the government which aim at influencing the budget in order to induced effective demand by various economic units. For most economies, the fundamental objectives of fiscal policy include price stability, maintenance of balance of payments equilibrium, and promotion of employment, output growth and sustainable development. These objectives are necessary for the attainment of internal and external balance of value of money and promotion of long run economic growth (Mohamad et al., 2015). Blanchard (2009) defined fiscal policy as the government's management of the economy through the changes of its income andspending abilities envisioned to create conducive macroeconomic environment. However,

"The global economic crisis that broke out in 2008 has reawakened interest in fiscal policy. In the early stages of the crisis, there was a widespread turn to countercyclical fiscal stimulus. Furthermore, the recent euro area crisis has underlined the importance of long-term fiscal sustainability for macroeconomic stability. More subtly, the global crisis has also refocused interest in fiscal policy as an instrument for longerterm growth and development. In the potential "new normal" of continued sluggishness in the advanced world, developing countries have strong incentives to seek out new domestic engines for efficiency and productivity growth, as well as for greater equity in development. The potential of fiscal policy to promote these ends is therefore of great interest to developing country policy makers" Brahmbhatt (2012).

The effects of fiscal policy shocks are still a subject of lively debate, as neither theoretical nor empirical studies have reached a consensus on either the qualitative or quantitative properties of such effects (Franta, 2012). "The effectiveness of a fiscal policy in stimulating the real economy is an ongoing intellectual debate in prominent academic journals and columns with high-profile"

(Gaber, 2013). "The interest in the use of fiscal policy as an effective economic policy tool has been revived recently, since the global recession of 2008 hit the world. In spite of a large empirical literature, there remains substantial uncertainty about the size and even the direction of the effects of discretionary fiscal policy" (Yang, 
2013). In addition, the effects of fiscal policy on the macroeconomy are of ongoing interest to economic policymakers. There are frequent calls for fiscal policy actions, stylized facts on the macroeconomic impact of fiscal policy have not been established yet much in contrast to monetary policy effects (Tenhofen et al., 2010).

IMF (2016) stated that Ethiopia reached the completion point under the Heavily Indebted Poor Countries Initiative in 2004 and benefited from debt relief under the Multilateral Debt Relief Initiative in 2006. Public and publicly guaranteed (PPG) external debt fell in the years that followed, reaching a low of 18 percent of GDP in mid-2012 and by end of 2015/16 it is estimated at 30.2 percent of GDP and total (including domestic) public debt is estimated at 54.2 percent of

GDP. Thus, the country's public debt is very high (54.2\%). Therefore, Ethiopia needs to do more to achieve its vision of climate resilient middle-income status by 2025.For instance, reduction of the country's still high poverty levels, economic transformation, and generation of adequate and sustainable employment opportunities for the large and growing workforce. To that end, the government has launched the second five-year GTP II, which spans 2014/15-2019/20. GTP II is a continuation of GTP I (AfDB, 2016). However, Ethiopia's output growth during 2015/16 is estimated to have slowed down to 6.5 percent (IMF, 2016). Therefore, the knowledge of fiscal policy plays a crucial role in achieving the country's objective.

Our intuition here is analyzing the effects fiscal policy by decomposing total government spending, and examining their effect on the aggregate economy provide a more accurate picture than treating total as the fiscal policy variable. Thereafter, we propose a structural decomposition of total government spending in to two components as recurrent and capital expenditure. The paper provides estimates of the responses of macroeconomic aggregates to innovations in different government spending groups by replacing total government spending with each spending components separately. In a further step, the responses of the GDP components, private investment and consumption, to a shock to each spending component will be examined. Consequently, we are able to identify the potential 'crowding-out' or crowding-in effects of government expenditure on the private sector. Unambiguously, Bayesian estimation of the reduced form of VAR could improve our understanding of the effects of government expenditure shocks via incorporating prior information and knowledge.

\subsection{Objective of the Study}

The general objective of this study was to analyze the macroeconomic effects of fiscal policy shocks on the Ethiopian economy by using quarterly data that span from 2000/01Q1 to 2015/16Q4.

Specifically this paper envisioned to examine:

* The effects of public spending shocks on GDP, Inflation, exchange rate and interest rate.

\# The effects of category of public spending shocks on GDP, Inflation, exchange rate and interest rate.

\# The effects of public spending shocks on the composition of GDP, by analyzing potential "crowding-out" effects on private consumption and private investment and,

The rest of this paper is organized as follows: - Section II reviews the related theoretical and empirical literature. Section III explains the macroeconomic data set used. Section IV explains the empirical strategy used to identify the effects of fiscal policy shocks, and Section V provides the empirical analysis and discusses the results. Section VI concludes this paper with a summary, and policy implication.

\section{LITERATURE REVIEW}

Gaber et al, (2013) suggested thatin examining the transmission mechanism of fiscal policy one crucial assumption of any model is whether or not agents are forward looking as briefed on the above section(see section 2.1.2.1 and 2.1.2.2). In the absence of micro founded forward looking behaviour, expected future changes have no effects on current period decisions whereas forward looking consumers, armed with rational expectations, do react in the current period to expected changes in future variables.

A simple framework of a fiscal policy for growth and development help us to organize issues of fiscal policy shock. First, what are the development objectives to which a fiscal policy should contribute (Figure 2.1)? Growth is clearly one of the objectives, though policy makers may want to go beyond the standard focus on GDP growth and consider broader measures in stimulus come, or even expand the focus to growth in a comprehensive measure of wealth, poverty reduction, social inclusion, and equity have complex links to growth, but also are rightly viewed as independent development objectives, because the distributional outcomes of market processes may not necessarily ridicule with society's normative views on equity. Finally, although sometimes overlooked, there is protection against risk and vulnerability to shocks, which, assuming that most people are risk averse, is also an element of social welfare (Brahmbhatt et al., 2012).

Nevertheless, one cannot simply assume that there is a role for a government in advancing these development objectives. Ostrom (1990) stated that there must be a clear rationale for public action rather than relying on private markets or on the kinds of self-organizing. The traditional rationale for fiscal policy proposed is still useful: fiscal policy should aim to promote macroeconomic stabilization, improve resource allocation, and address distributional disparities (see Figure 2.1). 
Musgrave (1959) indicated that the stabilization rationale has both short- and long-term aspects. The shortrun aspect focuses on the possibility of using countercyclical fiscal policy to offset the impact of macroeconomic shocks that create large or persistent gaps between aggregate demand and potential output, thereby helping to avert both excessive cyclical unemployment and inflationary pressure. From a longer-term perspective, stabilization is also concerned with keeping fiscal deficits and public debt on a sustainable path, so that public finances do not themselves become a source of macroeconomic instability. As for the resource allocation rationale of fiscal policy, the focus is on the potential for the government to improve economic performance through expenditure and tax policies that boost efficiency and improve long-term development performance by dealing with critical market failures.

As shown in Figure (2.1) the government must remain solvent (able to pay off its debts at some future time), liquid (able to meet its current outgoings), and credible (retaining the confidence of investors in its solvency and liquidity). The effectiveness of fiscal programs depend crucially on the quality of public financial management institutions in a country. For instance the effectiveness of fiscal policy can be seen in terms of: the efficiency with which revenues are raised, the cost_effectiveness of public service delivery, or how well public resources are protected from corruption and waste ( Canuto et al., 2012).

Indeed, the costs of government failures may even exceed the costs of the market failures the government is trying to address. Political economy factors and institutional capacity intimately affect a country's ability to actually implement sound fiscal policies (Figure 2.1). As elaborated in Figure 2.1 below the aims of the government are macroeconomic stabilization, resource allocation and distribution. To achieve these objectives, the instruments and institutions used are public spending levels, composition and efficiency, tax policies and revenue mobilization, financing and public finance sheet, and public financial management and governance. However, there are a number of constraints on the way that prevent these objectives from being achieved as expected. Some of these constraints are political economy, fiscal sustainability and efficiency costs of taxation and borrowing.

\section{Development objectives}

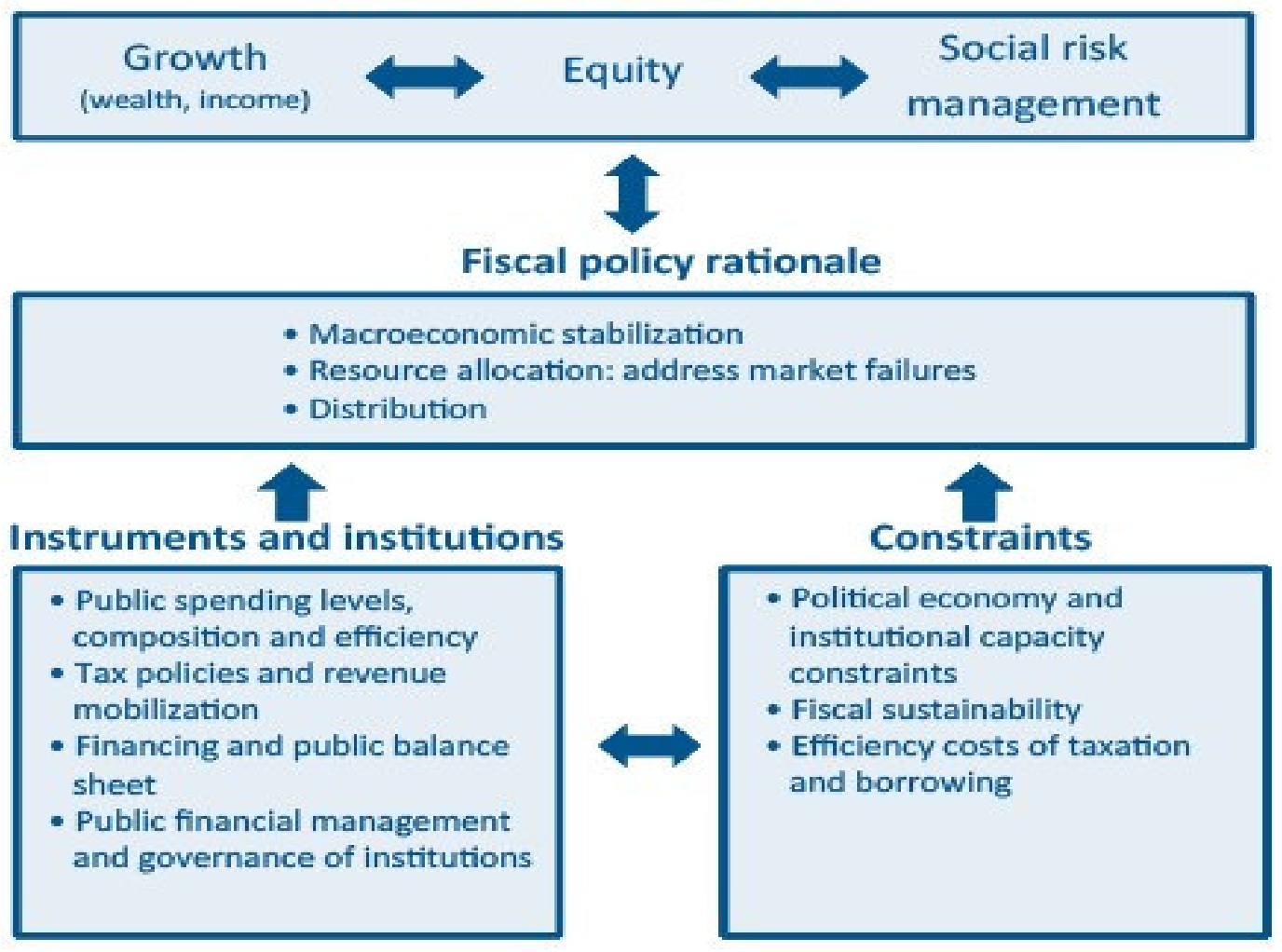

Figure 2.1. Fiscal Policy for Growth and Development: A Framework Source: Brahmbhatt et al., (2012).

There are a few related studies conducted in Ethiopia. For instance, Teshome (2006) examined the impact of government spending on economic growth and came up with the conclusion that government spending does not have significant insinuation to explain growth in the short-run.

Daniel (2012) analyzed dynamic effects of fiscal policy shocks on some macroeconomic variables excluding debt feedback rule. He examined the impulse responses of GDP, inflation and interest to the shocks of tax revenue 
and government expenditure. He found that tax shocks had a positive impact on output but little impact on inflation, whereas government spending shocks had an expansionary effect on output and have an inflationary impact in the short run.

Mathewos (2015) investigated the macroeconomic effects of fiscal policy shocks in Ethiopia using the Structural Vector Auto Regressive model (SVAR) by considering the feedback effects of public debt. His result confirms the argument that ignoring the reactions of fiscal and macro variables to the debt level produces incorrect estimates of the effects of fiscal policy in Ethiopia. He concluded that, shocks in government spending have an expansionary effect on output; lead to quick rise in prices; produce a small varied effect on the cost of debt; decrease nominal exchange rate in the long run and make debt-to-GDP ratio increase. Alternatively, shocks in revenue have a less clear cut, and small positive effect on output; a temporary price stabilization effect; no meaningful effect on the cost of debt; and less stabilization effect on debt- to-GDP ratio.

\section{MACROECONOMIC DATA}

We employed a quarterly data set on macroeconomic and fiscal variables. The variables included as major macroeconomic variables assumed to give a quick response to fiscal policy shocks are real gross domestic product, private consumption, private investment, inflation, interest rate and nominal exchange rate whereas government expenditure, government revenue and public debt are fiscal variables. The study used the quarterly data over the period of 2000/01Q1 up to 2015/16Q4 due to availability of organized data in between these years. Pedro (2011) stated that the use of high frequency data offers many advantages over that of low frequency data. The use of quarterly fiscal data allows us to identify more precisely the effects of fiscal policies since it capture intra-year dynamics and gives the possibility for larger samples so as to avoid the vanishing degrees of freedom in estimation. The data on CPI as a proxy for inflation, nominal exchange rate and interest rate were obtained from the National Bank of Ethiopia (NBE); whereas the quarterly fiscal data are obtained from the Ministry of Finance and Economic Cooperation of Ethiopia. Lastly, the annual data on Real GDP, private consumption and private investment are obtained from the National Planning Commission of Ethiopia, MoFEC and NBE. However, the quarterly data on real GDP, private consumption and private investment are mandatory to look at crowd-out and crowd-in effects of fiscal policy shocks. That is why we "quarterise" the real GDP, private investment, and private consumption using linear match last method of disaggregation by assuming real GDP and the growth of its components as a linear trend as suggested by Kitov (2005). He assumed the linear growth trend for real GDP and its components. All variables are expressed in logarithm apart from interest rate and seasonally adjusted before estimation

\section{The Bayesian VAR Model}

We employed the Bayesian methodology to estimate our model. Recently Bayesian VAR methodology has become a relevant tool to evaluate the effects of macroeconomic shocks (for instance, see Doan et al. 1984; Litterman 1986; Ritschl and Woitek 2000; Caldara and Kamps 2008; Koop and Korobolis, 2010, Afonso and Sousa 2009, 2012,Michal Franta, 2012, and Bobasu, 2016). The Bayesian approach offers a solution to the curse of dimensionality problem by shrinking the parameters via the imposition of priors (Koop and Korobolis, 2010, and Michael Franta, 2012). Koop and Potter (2003), Wright (2003), and Stock and Watson (2005, 2006) have explored the use of the Bayesian approach in relatively small systems, while De Mol et al. (2008) and Banbura et al. (2010) suggested the appropriateness of the Bayesian approach in systems with a large number of predictors compared to the small sample sizes that are essential in fiscal policy analysis.

Based on Cicarelli \& Rebucci (2003), and Koop and Korobolis (2010) the typical VAR model for $\mathrm{n}$ - dimension column vector $Y_{t}$ can be written as shown below for this study:

$\boldsymbol{Y}_{t}=\boldsymbol{C}+\sum_{p=1}^{L} \boldsymbol{b}_{i} \boldsymbol{Y}_{t-p}+\boldsymbol{D} \boldsymbol{Z}_{t-p}+\boldsymbol{\varepsilon}_{t}$

Where Yt is $\mathrm{n} \times 1$ vectors of endogenous variables; $\mathrm{D}$ is $\mathrm{n} \times \mathrm{d}$ parameter matrix, $\mathrm{Zt}$ is $\mathrm{d} \times 1$ dimension vector of exogenous variables; $\varepsilon_{t}$ is $n \times 1$ vector of independently, identically, and normally distributed (n.i.i.d) error terms:and $\left(\boldsymbol{b}_{i}, i=1,2, \ldots, L\right)$ is $\mathrm{n} \times \mathrm{n}$ coefficients matrices of VAR model. Covariance matrix of error term is $\Sigma$. Hence, $\varepsilon_{\mathrm{t}} \sim \operatorname{iid}(0, \Sigma)$. In order to introduce the Bayesian estimation technique Eq. (4.1) can be rewritten in shortened form as follows;

$\boldsymbol{Y}_{t}=\boldsymbol{X}_{t} \boldsymbol{\beta}+\boldsymbol{\varepsilon}_{t}$

where $\quad \mathrm{X}_{\mathrm{t}}=\quad\left(\mathrm{I}_{\mathrm{n}} \otimes \mathrm{W}_{\mathrm{t}-1}\right) \quad$ is $\mathrm{n} \times \mathrm{nk} \quad$ matrix, $\quad W_{t-1}=\left(\begin{array}{lllllll}\boldsymbol{C}^{\prime} & \boldsymbol{Y}_{t-1}^{\prime} & \boldsymbol{Y}_{t-2}^{\prime} & \cdots & \boldsymbol{Y}_{t-L}^{\prime} & \boldsymbol{Z}_{t}^{\prime}\end{array}\right) \quad$ is $\quad 1 \times \mathrm{k} \quad$, and $\beta=\operatorname{vec}\left(\mathrm{b} 1, \mathrm{~b} 2, \mathrm{~b} 3,,,{ }_{,},{ }_{,},{ }_{,},{ }_{,},{ }_{,},{ }_{,},{ }_{,},{ }_{,}, \mathrm{bp}, \mathrm{D}\right)$ is $\mathrm{nk} \times 1$. The unknown parameters of the model are $\mathrm{B}$ and $\Sigma$. Estimation of the parameters is quite straightforward. By combining the likelihood function of the parameters which is the probability density of the data conditional on the model's parameters given below

$L(Y / \beta, \Sigma) \propto|\Sigma|^{-\frac{T}{2}} \exp \left\{-\frac{1}{2} \sum_{t}\left(\mathrm{Y}_{\mathrm{t}}-\mathrm{X}_{\mathrm{t}} \beta\right)^{\prime} \Sigma^{-1}\left(\mathrm{Y}_{\mathrm{t}}-\mathrm{X}_{\mathrm{t}} \beta\right)\right\}$ 
joint prior distribution on the parameters, $p(\beta, \Sigma)$, the joint posterior distribution of the parameters conditional on the data is given as follows (we followCicarelli \& Rebucci, 2003, and Del Negro et al., 2009).

$p(\beta, \Sigma)=\frac{p(\beta, \Sigma) L(y / \beta, \Sigma)}{p(Y)} \propto p(\beta, \Sigma) L(y / \beta, \Sigma)$

where $\propto$ represents "proportional to" (see Del Negro et al., 2009, Kociecki et al., 2014). The commonly used prior distribution is the prior suggested by Litterman (1980), which is known as

"Minnesota prior". This prior, transforms the VAR model into random walk process for each variable (Luetkepohl, 2011). At the same time, imposing Minnesota priors is the simplest way of dealing with the variance covariance matrix of the VAR coefficients (Bobasu, 2016). In addition, the Minnesota prior expresses the degrees of uncertainty and the specification of prior variance for each coefficients of the variables in the model (Litterman, 1986) and (Ciccarelli and Rebucci, 2003).

Given equation (4.1) the discussion above can be formalized as follows.

Let $\beta=\operatorname{vec}\left(\Gamma_{1}, \Gamma 2, \Gamma 3,,,,,,,,,,,,,,, \Gamma \mathrm{p}\right) \ldots \ldots \ldots \ldots \ldots \ldots \ldots(4.5)$ be the vector of all the dynamic coefficients of the model.

The Minnesota prior can be specified as $\beta \sim \mathrm{N}(\beta, \mathrm{V})$.

where $\underline{\beta}$ and $\underline{V}$ are the prior mean and variance of the coefficients, respectively. This approach is popular and used due to its simplicity in computation and interpretation. A big advantage of the Minnesota prior is that it leads to simple posterior inference involving only the normal distribution (Korobolis and Koop, 2010).

After imposing prior restrictions, we derive the conditional posterior for the coefficients and the variancecovariance matrix of the VAR model. The main advantage of using Bayesian estimation is that it brings additional information into the model, by setting the priors, and therefore the analysis is more accurate and more precise( Franta,2012).

The additional information brought about by the data series help to derive the posterior distribution of the coefficients. The fiscal shocks are identified using a Cholesky identification scheme. In VARs Model, the priors can take many forms. Examples are a general shrinkage of all coefficients towards zero, shrinkage towards specific typical dynamic patterns, and Shrinkage towards fully specified dynamic stochastic general equilibrium models (Del Negro and Schorfheide, 2004, and Sims and Zha, 1998). Details on hyperparameter values are given in the next subsection.

Litterman (1980) stated that in Minnesota prior approach the coefficient of the first-own lag is set equal to one and all the other coefficients, including all the other own-lag coefficients and the coefficients for the other variables in the BVAR system, are set equal to zero. We are left with the task of choosing good values of hyperparameters for this study purpose. Even though there are several ways to do this a researcher is free to set these hyperparameters to any values i.e., your priors are your priors (Nason, 2016). The standard values of hyperparameters recommended by Sims and Zha(1998) are used since they are applicable and works well in practice even if the length of time periods and system size vary(Wind,2015). As all the data are in log levels except for interest rate, we followed Litterman (1986). In addition, we set the prior value of the autoregressive coefficients on its own first lag for each variable to one. Hence, the value of lambda $1=0.2$ (overall tightness), lambda2=1(crossequation tightness) and lambda3=1(harmonic lag decay). Therefore, in this paper, BVAR model with a Minnesota prior (MVAR) is applied to the Ethiopian economy for assessing the effects of fiscal policy shock.

\section{The Government Spending Effects on Macroeconomic Variables}

The impulse response functions are plotted for the first 10 quarters only. Since we estimate the BVAR in levels there are unit roots or near unit roots in the system. For these cases Phillips (1998) shows that, if estimated long period ahead impulse responses are inconsistent i.e., they tend to random variables and not give the true impulse responses. Thus, in such a setting confidence in impulse responses for longer periods ahead does not seem to be high and impulse responses are generated only for 2.5 years.

According to Harris's (2007) recommendation looking at residual correlograms is a good idea when there are uncertainties in choosing the lag length of a VAR model. Hence, this study conducted residual correlograms for different order BVAR. Since there is no autocorrelation of residuals in the BVAR (4) model it is chosen and used as the benchmark.

The validity of analysis based on the benchmark model depends on how the estimated residuals perform when investigated with post-estimation diagnostic tests. These are test for the stability of the model, for autocorrelation, and for the normality of the estimated residuals. The test for stability shows that all roots of the characteristic polynomial lie inside the unit circle signifying that the model is stable and that VAR satisfies the stability condition. Therefore, our model is stable to generate impulse responses that can be used to examine the dynamic effects of fiscal policy shocks.

The LM test for residual autocorrelation indicates no evidence of autocorrelation at any of the first four lags at five percent significance level. The Jarque-Bera test for residual normality indicates that the residuals are normal. 
The null hypothesis states that residuals are multivariate normal and based on the result, the null hypothesis is accepted $^{1}$. However, normality is large sample property and given the small sample size, the residual normality can be better improved with a larger sample size.

In the following sub-sections, impulse responses estimated from the BVAR model for a period of 2.5 years are presented in figures and discussed in detail. Accumulated impulse responses are also estimated for the baseline model.

\section{i. Effects of Government Spending Shock}

Figure 5.1 displays the responses of the endogenous variables to a positive spending shock. Here we present the responses of net government expenditure, net tax revenue, real GDP, prices, interest rate and exchange rate to a unit shock to net government expenditure. We have the response of the endogenous variable to a unit shock and time horizon on the vertical and horizontal axis respectively. The immediate impact of a one percent increase in spending on itself is around 0.15 percent and then it has a cyclical pattern effect.

The government spending shock has a small positive impact on output from quarter two to six but the estimated impulse responses are mostly insignificant. The immediate impact of a one percent GDP increase in spending on output is almost zero. The GDP response turns slightly negative after two years in confirming with the findings of Yang (2013), Boiciuc (2015), Bobasu (2016), Heppke-Falk et al (2009). Despite a very small positive effect GDP is suggesting a 'crowding-in' effect and a 'Keynesian' pattern. Net taxes respond positively to the spending increase after the second quarter with the response peaking in the third quarter and immediately being eroded out and becoming negative via the horizon.

Response of NET_GOVERNMENT_EXPENDITU to NET_GOVERNMENT_EXPEND Response of NET_GOVERNMENT_REVENUE to NET_GOVERNMENT_EXPENDITU

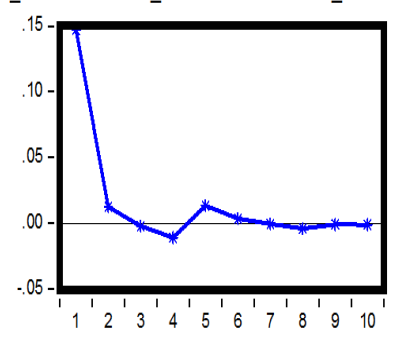

Response of INTEREST_RATE to NET_GOVERNMENT_EXPENDITU

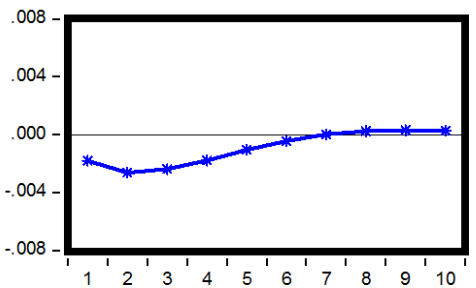

Response of EXCHANGE_RATE to NET_GOVERNMENT_EXPENDITU

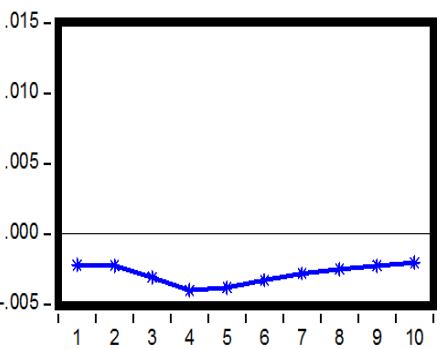

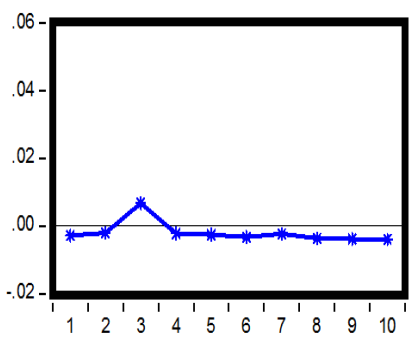

Response of REAL_GDP to NET_GOVERNMENT_EXPENDITU

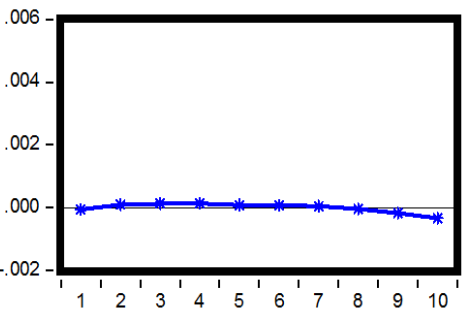

Response of INFLATION to NET_GOVERNMENT_EXPENDITU

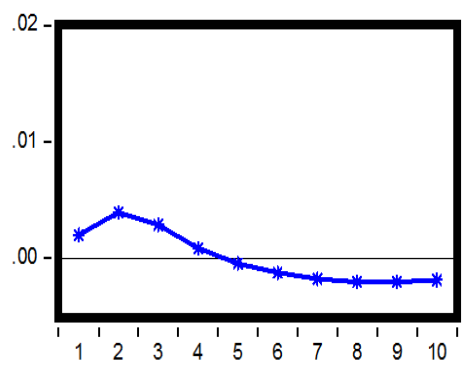

Figure 5.1: Responses of endogenous variables after the government spending shock

Inflation picks up slightly as a result of the government spending shock and the impulse responses are statistically significant in the first four quarters and peak at the second quarter. Then, it becomes negative after the fifth quarter. This implies that it has a positive effect on inflation in the short run.

Initially the interest rate responded negatively to the government spending shock and became positive at the $7^{\text {th }}$ quarter and turned positive in the subsequent quarters with a small effect. The nominal exchange rate shows a decline roughly for the first year of the response period following an increase in expenditure and then starts to improve even though it responded negatively to the shock.

\section{ii. The Effects of Disaggregated Government Spending Shocks}

In this section we investigate the effects of different components of fiscal policy on output, prices, interest rates, and exchange rate. To do so, we augment our basic 6-variable specification by splitting up either expenditure or 
revenue. Accordingly, we estimate BVARs with seven variables by splitting up fiscal variables into two components.

\section{i. The Effects of Net Government Expenditure Components}

In the first disaggregated specification, we include - in addition to net revenue - capital and recurrent expenditure as fiscal variables in the BVAR based on the major classifications of expenditure available. These two expenditure components add up to our previous net government expenditure variable, which is dropped. Concerning the relative ordering of the fiscal variables, we assume the priority of recurrent expenditure relative to capital expenditure, and then the priority of those two expenditure categories relative to net tax revenue.

Figure 5.3 shows the impulse-response functions to a positive shock in recurrent expenditure. Recurrent expenditure is positively affected by its own shock up to the $6^{\text {th }}$ quarter except at the $4^{\text {th }}$ quarter at which it becomes insignificant. Capital expenditure initially gives negative response and then it gives a positive, becoming cyclical for recurrent spending. More or less similar to the effect of total government spending, a positive shock to recurrent expenditure in Ethiopia has a persistent positive impact on real output. Recurrent expenditure appears not to be responsible for inflationary pressure in Ethiopia. Interest rate picks up slightly as a result of recurrent spending shocks and the impulse responses are positive in the first four quarters and peak at the $4^{\text {th }}$ quarter. Then, it dies out after the $9^{\text {th }}$ quarter. Although the initial response of exchange rate is small and negative in the first quarter, its overall response for the rest of the quarters remains negative and significant.

Figure 5.4 shows the impulse-response functions to a positive shock in capital expenditure. The capital expenditure is found to have a positive response in the first quarter and a cyclical response following a shock in capital spending where the effect is barely significant up on impact. In contrast to the effect of recurrent spending on output, capital expenditure is found to have a negative effect and finally become small. The reason could be the administrative lag and contractual bottleneck sometimes involved in executing most capital projects in Ethiopia support the finding of Atan for Nigeria (2015) and Lledo et al. (2011) suggested that capital expenditure is not significant for output since planned fiscal adjustments or expansions are less likely to be implemented the larger they are, the more inaccurate the growth forecasts they are based on, the more fragile the regulatory system in the country, and the weaker the institutions framing the design, approval, and execution of the budget in sub-Saharan Africa in general.

In contrast to recurrent expenditure shocks capital expenditure appears to be responsible for inflationary pressure in Ethiopia. It is positive throughout the horizon and significant like net government expenditure up until the $4^{\text {th }}$ quarter. In the short term, the interest rate responds negatively and then it is affected positively.

In the short term, the estimated impact on exchange rate is insignificant but becomes statistically significant after the $3^{\text {rd }}$ quarter. In other words, the nominal exchange rate is insignificant for the first year of the response period following an increase in capital expenditure. However, this is not the case for the subsequent forecast periods for it has showed improvement. This means that an expansion in capital spending causes a deterioration of nominal exchange rate in the short run.

This probably holds true since the country relies on imported goods for different capital projects. 
Response of RECURRENT_EXPENDITURE to RECURRENT_EXPENDITURE

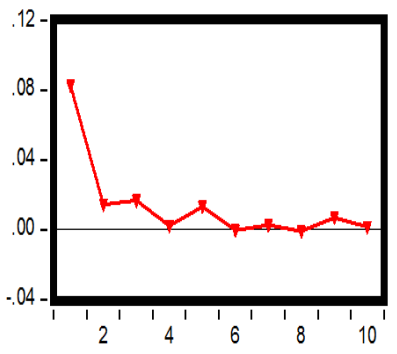

Response of CAPITAL_EXPENDITURE to RECURRENT_EXPENDITURE

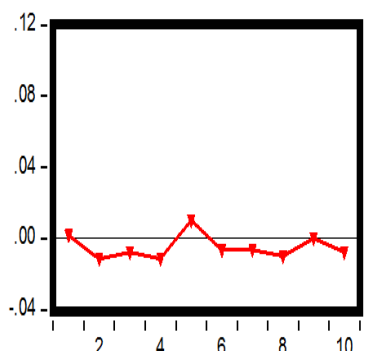

Response of NET_GOVERNMENT_REVENUE to RECURRENT_EXPENDITURE Response of REAL_GDP to RECURRENT_EXPENDITURE
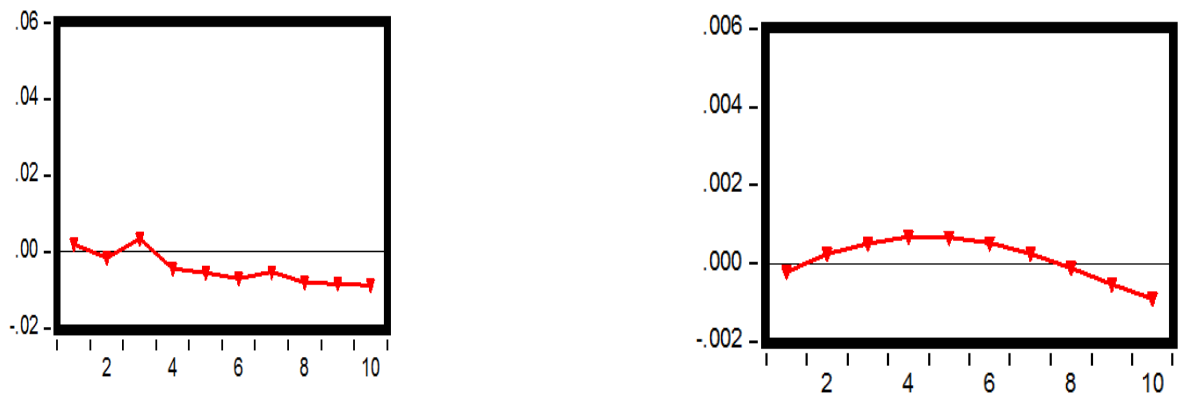

Response of INFLATION to RECURRENT_EXPENDITURE Response of INTEREST_RATE to RECURRENT_EXPENDITURE
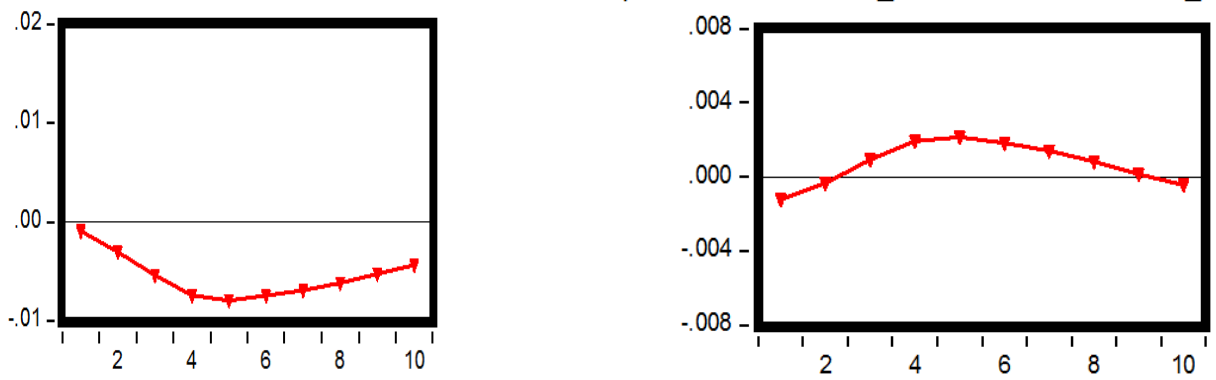

Response of EXCHANGE_RATE to RECURRENT_EXPENDITURE

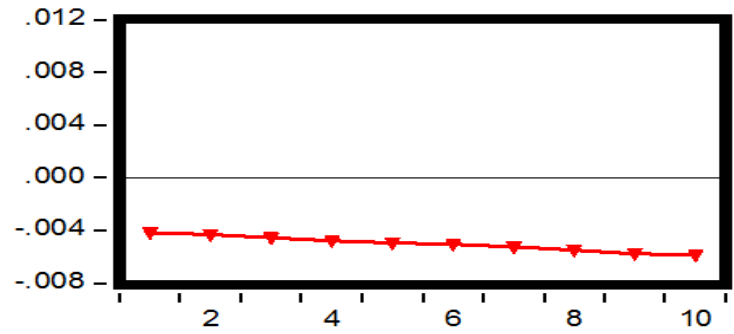

Figure 5.3: Responses of endogenous variables after recurrent expenditure shock 
Response of RECURRENT_EXPENDITURE to CAPITAL_EXPENDITURE Response of CAPITAL_EXPENDITURE to CAPITAL_EXPENDITURE

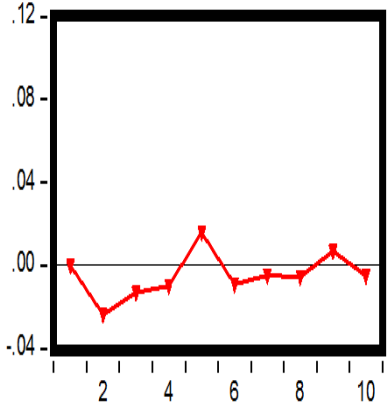

Response of NET_GOVERNMENT_REVENUE to CAPITAL_EXPENDITURE

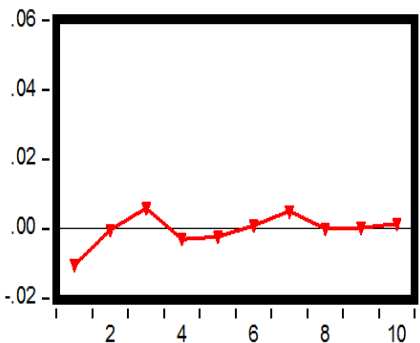

Response of INFLATION to CAPITAL_EXPENDITURE

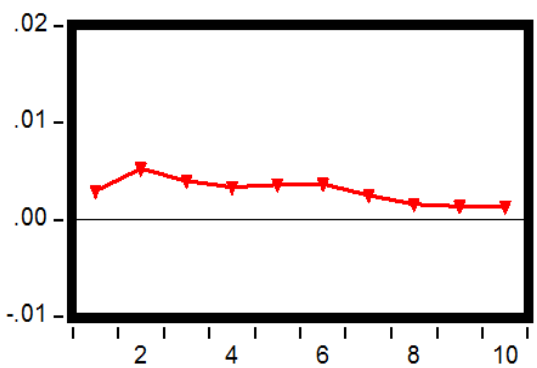

Response of EXCHANGE_RATE to CAPITAL_EXPENDITURE

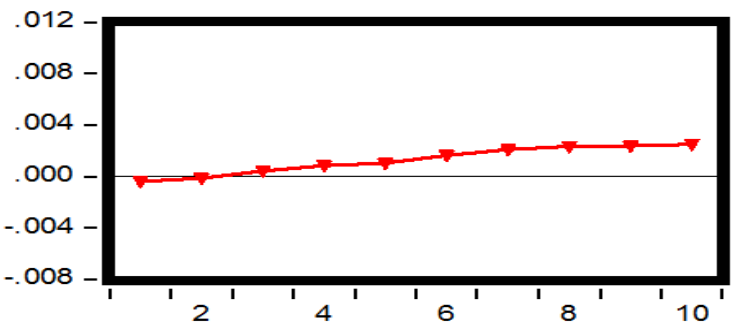

Figure 5.4: Responses of endogenous variables after capital expenditure shock

\subsection{The Effects of Government Spending Shocks on Private Consumption and Investment: On the Private Sector}

To get a more detailed picture of the effects of fiscal policy, we look at the response of GDP components, in particular private consumption and investment. Neoclassical theory broadly predicts that consumption should fall in response to a (temporary) spending shock, while New Keynesian models predict that consumption should increases. In the figure below the responses of consumption and investment to a spending and revenue shock in a 7- variable BVAR model are given. For this analysis real GDP has been dropped in this specification and replaced by private consumption and private investment.

Figure 5.7 shows the impulse-response functions to a positive shock in government spending. The impact of spending shock on private consumption is positive in the first eight quarters, and reaches its peak in the fourth quarter, hence, supporting the idea that government spending has an expansionary 'Keynesian' effect in the economy. Then, it starts to decline, becoming negative, although not significant. Contrary to a shock in government spending effect on private consumption, the effects of a revenue shock on private consumption is positive, very persistent and the trough is reached after seven quarters.

Interestingly, the investment response to a government revenue shock is positive, which is in line with the 
finding of Blanchard and Perotti (2002), Aschauer (1989),Argimon et al.(1997),Biau and Girard (2005),HepkeFak et al., (2006),Burnside et al., (2004),Giordano et al.,(2007),Grier and Tullock (1989). Similarly private consumption response to the shocks is positive, which replicates the results of Blanchard and perotti (2004), Hepke-Falk et al., (2006), Giordano et al., (2007), Fatas and Mihov (2001), Perotti (2004), and Biau and Girard (2005). Therefore, private consumption and private investment are not crowded out by net government spending and net government revenue.

Response of PRIVATE_CONSUMPTION to NET_GOVERNMENT_EXPENDITU

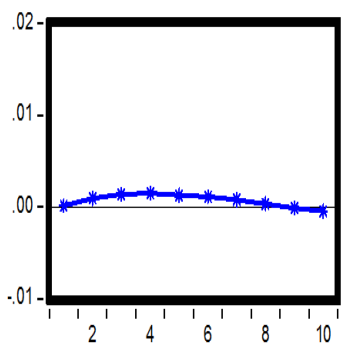

\section{Response of PRIVATE INVESTMENT to NET GOVERNMENT EXPENDITU}

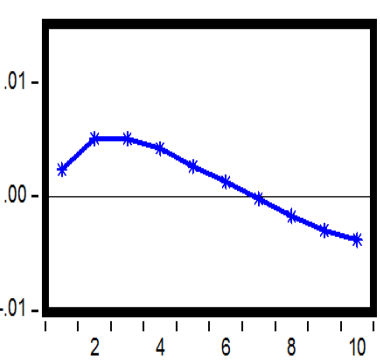

Figure 5.7: Responses of private consumption and private investment to government spending Shock

\subsection{The Response of Debt to GDP Ratio to Spending Shock}

Investigating the reaction of debt to fiscal policy shocks helps us to identify the relative importance of expenditure and revenue measures for its stabilization and/or reduction purpose. "A deficit financed policy change causes government debt to accumulate, which brings forth future policy adjustments that can affect both the current economy (through policy expectations) and the future economy (through the implementation of policy adjustments)" (Yang et al.,2003). Furthermore, "When the debt-to-output ratio rises, the government mainly relies on reducing its purchases and increasing income taxes to stabilize debt. When a fiscal shock hits the economy, it has a direct effect from the shock itself and an indirect effect through financing. When government investment increases or the capital tax rate decreases, higher debt is associated with higher investment at least in the short run" (Yang et al.,2003).

As can be seen from the figure below, a positive discretionary increase in government expenditure is estimated to increase the debt-to-GDP ratio for the entire horizon. When we turn to see the revenue shock effects on debt dynamics, initially it decreases the debt ratio. However, the duration of this response is only short lived and debt ratio embarks on to take a positive response via the horizon. In comparison to a spending shock this positive response of debt ratio to revenue shock further appears to be a bit larger in magnitude.

Accumulated Response of DEBT_TO_GDP_RATIO to NET_GOVERNMENT_EXPENDITU Accumulated Response of DEBT_TO_GDP_RATIO to NET_TAX_REVENUE
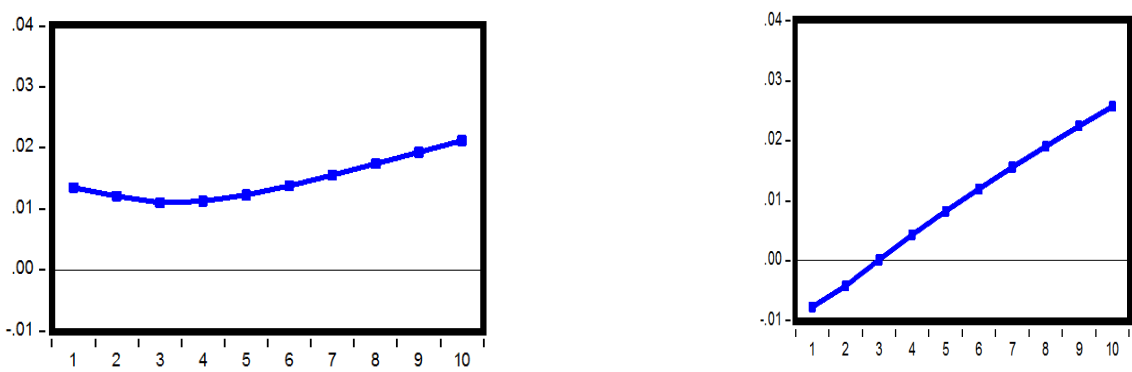

Figure 5.9: Accumulated response of debt ratio after the government spending and revenue shocks.

Several robustness checks are performed to make sure that the model yields a stable outcome. The first assumption considered and used is different order on fiscal variables: government spending decisions came first, then net tax revenue followed, and the vice versa. In the second check, the model is estimated with a different lag, as the lag selection criteria indicated. The third robustness check is conducted by using the Cholesky decomposition. Finally, different hyper-parameter values are used to see if the impulse response functions are robust results, both short periods and long periods of impulse response function results were considered.

Particularly, a different ordering of the variables in which net tax revenue is ordered next to government spending (Tenhofen et al.,2010) yields almost the same impulse response functions. This finding is similar to that of Blanchard and Perotti (2001). After all of these assumptions had been carried out, the results under different robustness checks were found to be similar to the one obtained in the benchmark model. Therefore, we can conclude that the model is robust. Henceforth, very similar impulse responses are estimated in all cases of robustness check methods listed above but they are not reported here. 


\section{Conclusion}

The effectiveness of a fiscal policy in stimulating the real economy is an ongoing intellectual debate. This paper assesses the macroeconomic effects of fiscal policy shocks in Ethiopia employing quarterly data for the period of 2000:Q1-2016:Q4 and using Bayesian Vector Auto Regression model with Minnesota prior. Following government spending shocks:- i) output has small positive feedback from quarter two to six quarters, but the estimated impulse responses are mostly insignificant:- ii) net taxes respond positively to the spending increase and immediately erode out and become negative via the horizon:-iii) inflation picks up slightly as a result of a government spending shock. This implies that it has inflationary pressure in the short run:- iv) initially the interest rate respond negatively to government spending shock and become positive at the $7^{\text {th }}$ quarter and positive in the subsequent quarters with small effect:-v) the nominal exchange rate shows a deterioration roughly for the first year of the response period and then starts to improve even if it respond negatively to the shock.

Furthermore, different spending components have different effects on macroeconomic aggregates depending on the underlying cause of the shock. Similar to the effect of total government spending, a positive shock to recurrent expenditure in Ethiopia has a persistent positive impact on real output. Recurrent expenditure appears not to be responsible for inflationary pressure in Ethiopia. Interest rate picks up slightly as a result of recurrent spending shocks and the impulse responses become positive, peak and then dies out. Although the initial response of exchange rate is small and negative in the first quarter, its overall response in the rest of the quarters remains negative and significant. In contrast to the effect of recurrent spending on output, capital expenditure is found to have a negative effect and finally become small. The reason could be the administrative lag and contractual bottlenecks sometimes involved in executing most capital projects in Ethiopia. In contrast to recurrent expenditure shocks, capital expenditure appears to be responsible for inflationary pressure in Ethiopia. In the short term, the interest rate responds negatively and then it is affected positively. The estimated impact on exchange rate is insignificant but becomes statistically significant after one year. Furthermore, the results support the idea of a 'crowding-in' effect as both private consumption and private investment react positively to the government Spending shocks. The empirical evidence shows that it is important to explicitly consider government Spending components separately in the model.

\subsection{Policy Implications}

Based on the empirical findings the following policy implications are suggested.

$>$ Government expenditure should not be taken as a stabilizing policy instrument due to its immediate inflationary pressure.

$>$ Current spending can be used to stimulate the economy at the expense of lower output in the long-run.

$>$ The government has to do on the administrative lag and contractual bottleneck appears in the country sometimes involved in executing capital projects.

$>$ A great caution should be taken to avoid an expansion in spending leads to large debt accumulation in the economy.

\section{REFERENCES}

$>$ AfDB (2016), "Federal Democratic Republic of Ethiopia Country Strategy Paper 20162020", EARC Department.

$>$ Afonso, A., and Sousa, R., (2009), “The Macroeconomic Effects of Fiscal policy”, European Central Bank Working Paper Series, No. 991.

$>$ Afonso, A. (2010), "Expansionary fiscal consolidations in Europe: new evidence", Applied Economics Letters, Taylor and Francis Journals, vol. 17(2), pages 105-109.

$>$ Afonso, A. and Sousa, R. (2012), “The macroeconomic effects of fiscal policy”, Applied Economics, 44(34), pp. 4439-4454.

$>$ Alesina A., and Ardagna, S. (1998), “Tales of fiscal adjustment”, Economic Policy, no 27

$>$ Aschauer, D. (1989), “Is Public Expenditure Productive?”,Journal of Monetary Economics,23:177-200.

$>$ Baldacci, E., Cangiano, M., Mahfouz, S., and Schimmelpfennig, A. (2001), "The Effectiveness of Fiscal Policy in Stimulating Economic Activity: An Empirical Investigation", Paper Presented at the IMF Annual Research Conference, International Monetary Fund.

$>$ Banbura, M., Domenico, G., and Lucrezia, R. (2010), “Large Bayesian Vector Auto Regressions”, Journal of Applied Econometrics 25 (1).

$>$ Biau, O., and Girard, E. (2005), "Politique budgét aireet dynamiqueéconomiqueen France: l'approche VAR structurel", Économie et Prévision, 169-171, 1-24.

$>$ Beetsma, R., and Giuliodori, M. (2011),"The Changing Macroeconomic Response to Stock Market Volatility Shock”,CESifo Working Paper Series No. 3652. 
D Blanchard, O., and Perotti, R. (2002), "An Empirical Characterization of the Dynamic Effects of changes in Government Spending and Taxes on Output”, Quarterly Journal of Economics, 119, 1329-1368.

$>$ Blanchard, O. (2009), "The Crisis: Basic Mechanisms, and Appropriate Policies", IMF Working paper WP/09/80, Washington: International Monetary Fund.

$>$ Bobasu, A. (2016), "Quantifying the Impact of Fiscal Policy on Economic Growth in the Romanian Economy: A Bayesian Approach", Journal of Economics, Business and Management, Vol.4, No. 1.

$>$ Brahmbhatt, M.,and Canuto, O. (2012), "Fiscal Policy for Growth and Development", the World Bank, Poverty Reduction and Economic Management Network, Economic Premise, No 91.

$>$ Burnside, C., Eichenbaum, M., and Fisher, J. (2004), "Fiscal Shocks and Their Consequences", Journal of Economic Theory 115, pp. 109-117.

$>$ Caldara, D., and Kamps, C., (2008), "What are the Effects of Fiscal Policy Shocks? A VAR-based Comparative Analysis", ECB Working Paper Series, 877.

$>$ Ciccarelli, M., and Rebucci, A. (2003), "Bayesian VARs: A Survey of the Recent Literature with an Application to the European Monetary System", IMF Working Papers 03/102, International Monetary Fund.

> Carmignani, F. (2010), “Cyclical Fiscal Policy in Africa”, Journal of Policy Modeling, Vol. 32, pp. $254-67$.

$>$ Christopher, A. and David, V. (2005), "The Macroeconomic Role of Fiscal Policy", Oxford Review of Economic Policy, vol. 21 no. 4, Oxford University Press.

$>$ Daniel, A. (2012), "Empirical Characterization of the Dynamic Effects of Fiscal Policy Shock on Key Macroeconomic variables in Ethiopia", MSc thesis, Addis Ababa University.

$>$ De Castro, F., and de Cos, H. (2008), "The Economic Effects of Fiscal Policy: The Case of Spain”, Journal of Macroeconomics", 30, pp. 1005-1028.

$>$ Del Negro, M. and Schorfheide, F. (2004), "Priors from General Equilibrium Models for VARS”, International Economic Review, 45(2), 643-673.

$>$ Doan, T., Robert B., and Christopher S. (1984), "Forecasting and Conditional Projection Using Realistic Prior Distributions”,Econometric Reviews,no 3.

$>$ Fatás, A., and Mihov, I. (2001), "The Effects of Fiscal Policy on Consumption and Employment: Theory and Evidence”, CEPR Discussion Paper No. 2760.

> Franta, M., (2012), "Macroeconomic Effects of Fiscal Policy in the Czech Republic: Evidence Based on Various Identification Approaches in a VAR Framework", CNB working paper series, 13.

> Gaber, S., Gruevski, I., \& Gaber, V. (2013), "The Effects of Discretionary Fiscal Policy on Macroeconomic aggregates", BEH-Business and Economic Horizons, 9(1), 33-40.

$>$ Giavazzi F. and M. Pagano (1996), "Non-Keynesian Effects of Fiscal Policy Changes: International Evidence and the Swedish Experience", Swedish Economic Policy Review, Vol. 3, pp. $67-103$.

$>$ Giordano, R., Momigliano, S, and. Perotti R (2007), “The Effects of Fiscal Policy in Italy: Evidence from a VAR Model”, European Journal of Political Economy 23(3), pp. 707-733.

$>$ Giudice, G., Turini A., and Jan in't Veld (2004), "Can Fiscal Consolidations be Expansionary in the EU? Expost evidence and ex-ante analysis”, European Economy, European Commission, Economic Papers, No 195.

> Grier, K. and Tullock, G. (1989), “An Empirical Analysis of Cross-National Economic Growth, 1951-1980”, Journal of Monetary Economics, 24, 259-279.

$>$ Harris, R. (1995). "Using Cointegration Analysis in Econometric Modeling." London, New York, Prentice Hall /Harvastor Wheat Sheaf.

$>$ Harris R. (2007), "Times Series Analysis and Forecasting."

$>$ Heppke-Falk, K.., Tenhofen, J., and Wolff B. (2006), "The Macroeconomic Effects of Exogenous Fiscal Policy Shocks in Germany: a Disaggregated SVAR analysis”, Deutsche Bundesbank, Discussion Paper N. 41.

$>$ Heppke-falk, K. Tenhofen J., and Wolff B. (2010), “The Macroeconomic Effects of Exogenous Fiscal Policy Shocks in Germany: A Disaggregated SVAR Analysis", Journal of Economics and Statistics 230(3), pp. 328355.

> IMF (2016), "Federal Democratic Republic of Ethiopia: 2016 Article IV Consultation Staff Report", IMF Country Report 16/322. Washington DC: International Monetary Fund.

> James M. (2016), "Bayesian Vector Autoregressions: Priors and Identification”, Department of Economics, Lecture note, North Carolina State University.

$>$ Kitov, I(2005), “Real GDP per Capita in Developed countries”, MPRA Paper No. 14450

$>$ Andrzej K., Micha R., and Michele C. (2014), "Bayesian Analysis of SVAR Models with Economic Priors”, European Central Bank, Kaiserstrasse 29, D-60311 Frankfurt am Main, 
Germany.

$>$ Koop, G. and Potter, S. (2003), "Forecasting in Large Macroeconomic Panels using Bayesian Model Averaging”, Staff Reports 163, Federal Reserve Bank of New York.

$>$ Koop, G. and D. Korobilis (2010), "Bayesian Multivariate Time Series Methods for Empirical Macroeconomics", Foundations and Trends in Econometrics 3(4), pp. 267-358.

$>$ Litterman R. (1980), “Techniques for Forecasting with Vector Auto Regressions”, University of Minnesota, Ph.D. Dissertation (Minneapolis).

$>$ Robert B. (1986), "Forecasting with Bayesian Vector Autoregressions": Five Years of Experience, Journal of Business \& Economic Statistics, Vol. 4, No. 1: 25-38.

$>$ Mankiw, G., (2001), "Lecture on Macroeconomics", fifth Edition, Worth publishers.

$>$ Mathewos H. (2015), "Effects of the Fiscal Policy Shocks under the Debt Feedback Rule in Ethiopia: Evidence from SVAR Model”, MSc thesis, Addis Ababa University.

$>$ Martínez-V, and Jorge Y. (2011), “Tax Structure in Latin America: it's Impact on the Real Economy and Compliance", CAF Working paper $\mathrm{N}^{\circ} 09$

$>$ Medee, N., and Nembee, S. (2011), "Econometric Analysis of the Impact of Fiscal Policy Variables on Nigeria's Economic Growth (1970 - 2009)”, International Journal of Economic Development Research and Investment, 2(1), 13-25.

$>$ Musgrave, R. (1959), "The Theory of Public Finance: A Study in Public Economy”, New York: McGrawHill.

$>$ Ostrom, E. (1990), "Governing the Commons: The Evolution of Institutions for Collective Action", Cambridge, UK: Cambridge University Press.

$>$ Parkyn, O., and Vehbi, T., (2013), "The Effects of Fiscal Policy in New Zealand: Evidence from a VAR Model with Debt Constraints", New Zealand Treasury Working Paper, 13/02.

$>$ Pedro, M. (2011), "Fiscal Dynamics in Ethiopia: The co-integrated VAR Model with Quarterly Data", Credit Research Paper, No.10/05.

$>$ Perotti, R. (2001), "What Do We Know About the Effects of Fiscal Policy?” Political fiscale, flessibilità dei mercati e crescita Milano: Angeli.

$>$ Perotti, R. (2002), “A Quarterly Database on Fiscal Policy in 5 OECD Countries”, in preparation, European University Institute.

$>$ Perotti, R. (2004), "Estimating the effects of fiscal policy in OECD countries", University of Bocconi, Working Paper.

$>$ Phillips, P. (1998), "Impulse Response and Forecast Error Variance Asymptotics in Nonstationary VARs", Journal of Econometrics 83: 21 -56.

$>$ Rena, R., and Kefela, T., (2011), "Restructuring a Fiscal Policy Encourages Economic Growth - A Case of Selected African Countries", Journal of Economics and Business, XIV (2), pp. 23-39.

$>$ Ritschl A. and Woitek U. (2000), "Did Monetary Forces Cause the Great Depression? A Bayesian VAR Analysis for the U.S. economy”, Working paper No. 50, Institute for Empirical Research in Economics, University of Zurich.

$>$ Sims A. and Tao Z. (1998), "Bayesian Methods for Dynamic Multivariate Models", International Economic Review 39(4), November, 949-68.

$>$ Stock H. and Watson W. (2005), "Implications of Dynamic Factor Models for VAR analysis", manuscript, Princeton University.

$>$ Tang H., Liu P. and Cheung C. (2011), "Changing Impact of Fiscal policy on Selected Asian Countries," Journal of Asian Economics.

$>$ Tanzi, V. (2008), "The Role of the State and Public Finance in the Next Generation", OECD Journal on Budgeting, Vol. 8, No 2.

$>$ Usenobong F., and Johnson A. (2015), "Macroeconomic Effects of Fiscal Policy Shock in Nigeria: A SVAR Approach", International Journal of Business and Economics Research. Vol. 4, No. 3, pp. 109-120. doi: 10.11648/j.ijber.20150403.

$>$ Wind D. (2015), “Technical Background Document for BVAR models used at CPB”, CPB Netherlands Bureau for economic policy analysis.

$>$ Wright, J. (2003), "Forecasting U.S. Inflation by Bayesian Model Averaging”, International Finance Discussion Papers 780, Board of Governors of the Federal Reserve System.

$>$ Yang, C. (2003), "Evidence of Tax Foresight", Mimeo, John Carroll University

$>$ Yang, W., (2013), "Macroeconomic Effects of Fiscal Policy", A Doctoral Thesis, Brunel University. 